\begin{tabular}{cl|l}
$\begin{array}{c}\text { Cellular Physiology } \\
\text { and Biochemistry }\end{array}$ & Cell Physiol Biochem 2012;30:123-136 & \multicolumn{2}{l}{ DOI: 10.1159/000339052 } & $\begin{array}{l}\text { O 2012 S. Karger AG, Basel } \\
\text { www.karger.com/cpb }\end{array}$ \\
\cline { 2 - 3 } & $\begin{array}{l}\text { Published online: June 18, 2012 } \\
\text { Accepted: May 14, 2012 }\end{array}$ & $1015-8987 / 12 / 0301-0123 \$ 38.00 / 0$
\end{tabular}

\title{
Quercetin Triggers Apoptosis of Lipopolysaccharide (LPS)-induced Osteoclasts and Inhibits Bone Resorption in RAW264.7 Cells
}

\author{
Chun Guo ${ }^{1}$ Guo-qing Hou ${ }^{1}$ Xue-dong $\mathrm{Li}^{1} \quad \mathrm{Xue} \mathrm{Xia}^{1}$ Dong-xin Liu ${ }^{1}$ Dong-yang \\ Huang ${ }^{2}$ Shi-xin $\mathrm{Du}^{1}$ \\ ${ }^{1}$ Department of Orthopaedics, the First Affiliated Hospital, Shantou University Medical College, \\ Shantou, ${ }^{2}$ Center for Molecular Biology, Shantou University Medical College, Shantou
}

\section{Key Words}

Quercetin $•$ Osteoclast $\cdot$ LPS $\cdot$ Receptor activator of nuclear factor- $\mathrm{KB}($ RANK) $\cdot$ Cyclooxygenase$2(\mathrm{COX}-2) \cdot$ Mitogen-activated protein kinases (MAPK)

\begin{abstract}
Aims: Quercetin, a flavonoid present in vegetables, has anti-inflammatory properties and potential inhibitory effects on bone resorption. Up to date, the effect of quercetin on lipopolysaccharide (LPS)-induced osteoclastogenesis has not yet been reported. In the current study, we evaluated the effect of quercetin on LPS-induced osteoclast apoptosis and bone resorption. Methods: RAW264.7 cells were non-treated, treated with LPS alone, or treated with both LPS and quercetin. After treatment, the number of osteoclasts, cell viability, bone resorption and osteoclast apoptosis were measured. The expressions of osteoclast-related genes including tartrate-resistant acid phosphatase (TRAP), matrix metalloproteinase-9 (MMP9) and cathepsin $K(C K)$ were determined by real-time quantitative polymerase chain reaction (qPCR). Protein levels of receptor activator of nuclear factor- $\kappa B$ (RANK), tumor necrosis factor receptor-associated factor 6 (TRAF6), cyclooxygenase-2 (COX-2), Bax, Bcl-2 and mitogenactivated protein kinases (MAPKs) were measured using Western blotting assays. The MAPK signaling pathway was blocked by pretreatment with MAPK inhibitors. Results: LPS directly promoted osteoclast differentiation of RAW264.7 cells and upregulated the protein expression of RANK, TRAF6 and COX-2; while quercetin significantly decreased the number of LPS-induced osteoclasts in a dose-dependent manner. None of the treatments increased cytotoxicity in RAW264.7 cells. Quercetin inhibited mRNA expressions of osteoclast-related genes and protein levels of RANK, TRAF6 and COX-2 in LPS-induced mature osteoclasts. Quercetin also induced apoptosis and inhibited bone resorptive activity in LPS-induced mature osteoclasts. Furthermore, quercetin promoted the apoptotic signaling pathway including increasing the phosphorylation of p38-MAPK, c-Jun $\mathrm{N}$-terminal kinases/stress-activated protein kinases
\end{abstract}




\begin{tabular}{|c|c|c|}
\hline $\mathrm{Col}$ & Cell Physiol Biochem 2012;30:123-136 & \\
\hline and Biochemistry & $\begin{array}{l}\text { DOI: 10.1159/000339052 } \\
\text { Published online: June 18, } 2012\end{array}$ & $\begin{array}{l}\text { (c) } 2012 \text { S. Karger AG, Basel } \\
\text { www.karger.com/cpb }\end{array}$ \\
\hline
\end{tabular}

(JNK/SAPK), and Bax, while inhibited Bcl-2 expression. Conclusions: Quercetin could suppress LPS-induced osteoclast bone resorption through blocking RANK signaling and inhibiting the expression of osteoclast-related genes. Quercetin also promoted LPS-induced osteoclast apoptosis via activation of the MAPK apoptotic signaling pathway. These findings suggest that quercetin could be of potential use as a therapeutic agent to treat bacteria-induced bone resorption.

Copyright $\odot 2012$ S. Karger AG, Basel

\section{Introduction}

Bone is a dynamic tissue that constantly undergoes remodeling where a coupled process of bone formation and resorption continues throughout life [1]. This process allows physiological bone growth, repair of damaged bones, and is important for the regulation of systemic calcium and phosphate levels. Chronic osteomyelitis, a bone infectious disease, is a dysregulation of this process, which results in excessive bone resorption. The receptor activator of nuclear factor- $\mathrm{KB}$ ligand (RANKL) is a key factor in regulating the process of osteoclast differentiation and maintaining the survival of mature osteoclasts [2]. RANK signaling plays a critical role in regulating osteoclast differentiation and bone resorptive activity. RANK is activated by RANKL via the tumor necrosis factor (TNF) receptor-associated factor 6 (TRAF6), which in turn induces the activation of mitogen-activated protein (MAP) kinases (MAPK) [3].

Lipopolysaccharide (LPS), a component of the outer membranes of all Gram-negative bacteria, is the first bacterial component shown to be capable of inducing bone resorption in vitro [4]. LPS induces production of cytokines including TNF- $\alpha$ by fibroblasts, macrophages, and other cells, which can further induce osteoclast formation and activation [5]. Moreover, LPS can promote osteoclast differentiation, fusion, survival and activation independent of IL-1, TNF- $\alpha$, and RANKL [6-9]. However, up to date, effective therapeutic treatments for LPS-induced bone destruction are limited to antibiotics and surgical repairs in chronic inflammatory diseases. Therefore, the research and development of potential drugs that can inhibit LPS induced osteolysis remains a major goal in the prevention of bone destruction in infective bone diseases.

Quercetin, as a dietary flavonoid, has been highlighted as a bioactive substance due to its biological, pharmacological, and medicinal features. Evidence suggests that quercetin inhibits bone loss by affecting osteoclastogenesis and regulating a variety of systemic and local factors such as hormones and inflammatory cytokines [10-12]. Moreover, quercetin is reported to inhibit LPS-induced MAPK activation, and cyclooxygenase-2 (COX-2) expression [13].

The aim of the current study was to evaluate the effect of quercetin on LPS-induced osteoclast bone resorptive activity and induction of apoptosis. We also aimed to clarify the inhibitory mechanism of quercetin on MAPK phosphorylation, as well as on the expression of RANK/TRAF6 and COX-2 in LPS-induced osteoclasts.

\section{Materials and Methods}

\section{Reagents}

Escherichia coli LPS (serotype 055:B5), quercetin, Leukocyte Acid Phosphatase Kit 387-A, 4-(2hydroxyethyl)-1-piperazineethanesulfonic acid (HEPES) and Hoechst 33258 were purchased from Sigma Co. (St Louis, MO, USA). Protease inhibitor cocktail and selective MAPK inhibitors PD98059, SB203580 and SP600125 were purchased from Calbiochem (San Diego, CA, USA). Alpha modified-minimum essential medium $(\alpha-\mathrm{MEM}), 10 \%$ fetal bovine serum (FBS), penicillin/streptomycin and TRIzol $^{\circledR}$ reagent were purchased from Gibco (Gibco, Rockville, MD). Primary antibodies against phosphorylated p38-MAPK, total c-Jun N-terminal kinase (JNK), phosphorylated JNK, extracellular signal regulated kinase (ERK1/2), 


\section{Cellular Physiology and Biochemistry \\ Cell Physiol Biochem 2012;30:123-136 \\ \begin{tabular}{l|l}
\hline DOI: $10.1159 / 000339052$ & (C) 2012 S. Karger AG, Basel
\end{tabular} \\ Published online: June 18, 2012 \\ www.karger.com/cpb \\ Guo/Hou/Li/Xia/Liu/Huang/Du: Quercetin Study in LPS-induced Osteoclasts}

phosphorylated ERK 1/2, Bax, Bcl-2 and COX-2 were purchased from Cell Signaling Technology (Beverly, MA). Primary antibodies against RANK, TRAF6 and $\beta$-actin were purchased from Santa Cruz Biotechnology (Santa Cruz, CA, USA). Mouse macrophage RAW 264.7 cell line that can be induced to differentiate into osteoclasts was obtained from the American Type Culture Collection (ATCC, Manassas, VA). Other chemicals and reagents used in this study were of analytical grade.

\section{Cell culture}

RAW 264.7 cells were grown in $\alpha$-MEM supplemented with $10 \%$ (v/v) FBS, 1\% (v/v) penicillinstreptomycin solution, $10 \mathrm{mM}$ HEPES solution and incubated at $37^{\circ} \mathrm{C}$ in $5 \% \mathrm{CO}_{2}$ humidified air. Medium was changed every $3 \mathrm{~d}$. For the cell viability assay, cells were seeded at $1 \times 10^{3}$ cells $/ \mathrm{cm}^{2}$; for other experiments, cells were seeded at $4 \times 10^{4}$ cells $/ \mathrm{cm}^{2}$. RAW264.7 cells were seeded into culture dishes and incubated overnight before treatment.

To evaluate the effect of LPS-induced osteoclastogenesis, cells were treated with $10,50,100,200$, or $1000 \mathrm{ng} / \mathrm{mL}$ LPS or without LPS for $4 \mathrm{~d}$ until differentiation. To evaluate the effect of quercetin on LPS-induced mature osteoclast apoptosis, RAW264.7 cells were treated with $100 \mathrm{ng} / \mathrm{mL}$ LPS for $4 \mathrm{~d}$. On differentiation day 4 , cells were treated with $5,10,15,25$, or $50 \mu \mathrm{M}$ quercetin or without quercetin in the presence of LPS (100 $\mathrm{ng} / \mathrm{mL})$.

\section{Tartrate-resistant acid phosphatase staining}

RAW264.7 cells were incubated with LPS at $100 \mathrm{ng} / \mathrm{mL}$ for $4 \mathrm{~d}$. On differentiation day 4, cells were treated with $5,10,15,25$, or $50 \mu \mathrm{M}$ quercetin or without quercetin for an additional 24 and $48 \mathrm{~h}$ in the presence of LPS (100 ng/mL). Cells were washed with phosphate-buffered saline (PBS) and fixed in $4 \%$ $(\mathrm{v} / \mathrm{v})$ paraformaldehyde at room temperature for $15 \mathrm{~min}$. Cells were stained with TRAP using the Leukocyte Acid Phosphatase Kit $387-\mathrm{A}$ at $37^{\circ} \mathrm{C}$ for $60 \mathrm{~min}$. Stained cells were then applied for microscopy (Olympus IX71, Olympus Optical, Tokyo, Japan). Osteoclasts were identified as TRAP-positive cells with three or more nuclei in each cell.

\section{Cell viability assay}

Cell viability was measured with the Cell Counting Kit-8 (Dojindo Molecular Technologies, MD) according to the manufacturer's protocol. RAW264.7 cells $\left(1 \times 10^{3}\right.$ cells $\left./ \mathrm{cm}^{2}\right)$ were seeded into 96 -well flat bottom plates and incubated overnight before experiment. To evaluate the effect of quercetin on preosteoclastic cell viability, cells were treated with $5,10,15,25$, or $50 \mu \mathrm{M}$ quercetin or without quercetin for $24 \mathrm{~h}$ and $4 \mathrm{~d}$. To evaluate the effect of quercetin on the viability of mature osteoclasts, RAW264.7 cells were incubated with LPS at $100 \mathrm{ng} / \mathrm{mL}$ for $4 \mathrm{~d}$ before treatment with $5,10,15,25$, or $50 \mu \mathrm{M}$ quercetin or without quercetin in the presence of LPS $(100 \mathrm{ng} / \mathrm{mL})$ for $24 \mathrm{~h}$. The absorbance of each sample was measured at 450 nm using a microplate reader (TECAN, Salzburg, Austria). All treatments were performed in triplicate.

\section{Bone resorption pit assays}

Bone resorption pit assays were conducted on as previously described [14]. RAW264.7 cells $\left(1 \times 10^{4}\right.$ cells $/ \mathrm{cm}^{2}$ ) were plated onto 150 - $\mu$ m-thick bovine cortical bone slices in culture dishes of 25 -mm-diameter and incubated overnight before experiment. The cells were then treated with LPS for $6 \mathrm{~d}$. From differentiation day 6 when the mature osteoclasts were functionally activated, cells were treated with $5,10,15,25$, or 50 $\mu \mathrm{M}$ quercetin or without quercetin in the presence of $100 \mathrm{ng} / \mathrm{mL}$ LPS. Cell culture media was changed every $3 \mathrm{~d}$ with the same additions of quercetin and LPS until differentiation day 15, when cells were washed with PBS and fixed in $4 \%(\mathrm{v} / \mathrm{v})$ paraformaldehyde. Fixed cells were then treated with $2 \mathrm{M} \mathrm{NaOH}$ and sonicated to remove cells. The resorption pits were stained with $1 \%$ toluidine blue- $1 \%$ borate for $5 \mathrm{~min}$. The images of resorption pit were visualized and captured with a light microscope (Olympus IX71) and quantified by the number of resorption pits formed per unit area.

\section{Study of osteoclast apoptosis}

To measure apoptosis, we performed Hoechst 33258 staining to visualize nuclear morphology and nucleosomal DNA fragmentation in osteoclasts. RAW264.7 cells $\left(4 \times 10^{4}\right.$ cells $\left./ \mathrm{cm}^{2}\right)$ were seeded into 12 -well plates and incubated overnight before experiment. The cells were treated with $100 \mathrm{ng} / \mathrm{mL}$ LPS for $4 \mathrm{~d}$. On day 4 , cells were treated with or without quercetin in the presence of $100 \mathrm{ng} / \mathrm{mL} \mathrm{LPS} \mathrm{for} 24 \mathrm{~h}$. At the end of the treatment with quercetin, cells were washed to remove non-adherent cells, and the adherent cells were 


\begin{tabular}{|c|c|c|}
\hline & Cell Physiol Biochem 2012;30:123-136 & \\
\hline and Ri & $\begin{array}{l}\text { DOI: 10.1159/000339052 } \\
\text { Published online: June 18, } 2012 \\
\end{array}$ & $\begin{array}{l}\text { () } 2012 \text { S. Karger AG, Basel } \\
\text { www.karger.com/cpb }\end{array}$ \\
\hline
\end{tabular}

Table 1. Sequences of PCR primers used for real time quantitative PCR.

\begin{tabular}{lllc}
\hline Gene & Accession No & \multicolumn{1}{c}{ Sequences $\left(5^{\prime} \rightarrow 3^{\prime}\right)$} & PCR product size $(\mathrm{bp})$ \\
\hline TRAP & NM_007388 & CACTCCCACCCTGAGATTTGT(F) & 118 \\
& & CATCGTCTGCACGGTTCTG $(\mathrm{R})$ & \\
MMP-9 & NM_013599 & $\begin{array}{l}\text { CTGGACAGCCAGACACTAAAG(F) } \\
\text { CTCGCGGCAAGTCTTCAGAG(R) }\end{array}$ & 145 \\
Cathepsin K & NM_007802 & GAAGAAGACTCACCAGAAGCAG(F) & 102 \\
& & TCCAGGTATGGGCAGAGATT(R) & 102 \\
$\beta$-actin & NM_007393 & GGCTGTATTCCCCTCCATCG(F) & 154 \\
& & CCAGTTGGTAACAATGCCATGT(R) & \\
\hline
\end{tabular}

fixed in 4\% paraformaldehyde solution for $10 \mathrm{~min}$. After wash with PBS, cells were incubated with $0.2 \mathrm{mM}$ Hoechst 33258 for $10 \mathrm{~min}$ in the dark. Cells with nuclei containing clearly condensed chromatin or cells with fragmented nuclei were scored as apoptotic; the results were expressed as the number of apoptotic cells. The images of apoptotic osteoclasts were obtained under a fluorescence microscope (Olympus IX71).

\section{Real-time QPCR}

Messenger RNA expression of osteoclast-specific genes including TRAP, matrix metalloproteinase9 (MMP-9), and cathepsin K $(C K)$ were determined by real-time qPCR. Total RNA was extracted from RAW264.7 cells either treated with 10,50,100, 200, or $1000 \mathrm{ng} / \mathrm{mL}$ LPS at day 4, or treated with LPS at $100 \mathrm{ng} / \mathrm{mL}$ for $4 \mathrm{~d}$, then with 5, 10, 15, 25, or $50 \mu \mathrm{M}$ quercetin in the presence of $100 \mathrm{ng} / \mathrm{mL}$ LPS for $24 \mathrm{~h}$. Total RNA was isolated using Trizol reagent and quantified by spectrophotometry. After isolation, $2 \mu \mathrm{g}$ total RNA from each sample was used for cDNA synthesis using the M-MLV1 ${ }^{\text {st }}$ Strand Kit (Invitrogen) according to the manufacturer's protocol. Primers for TRAP, MMP-9, cathepsin K, and $\beta$-actin are presented in Table 1. All real-time qPCR reactions were performed in the ABI PRISM 7700 sequence detection system (Applied Biosystems, Hamilton, New Zealand). In each reaction, $1 \mu \mathrm{L}$ cDNA, $9 \mu \mathrm{L} 2.5 \times$ SYBR Green RealMasterMix (Tiangen Biotech, Beijing, China), and $0.25 \mu \mathrm{M}$ forward and reverse primer in a total volume of $20 \mu \mathrm{L}$ were used. The reaction condition was as follows: 1 cycle of $95^{\circ} \mathrm{C}$ for $2 \mathrm{~min}$ followed by 40 cycles of $95^{\circ} \mathrm{C}$ for 20 $\mathrm{sec}, 63^{\circ} \mathrm{C}$ for $20 \mathrm{sec}$, and $68^{\circ} \mathrm{C}$ for $30 \mathrm{sec}$. Real-time qPCR for each sample was run in triplicate. $\beta$-actin was used as internal control, and all results were analyzed using the standard $2^{-\Delta \Delta C T}$ method described previously [15]. A Student's t-test was conducted to determine significant differences $(\mathrm{P}<0.05)$ between two treatment groups.

\section{Western blot analysis}

At the end of treatment, cell culture medium was aspirated and cells were detached in PBS by scrapping. Detached cells were transferred to fresh microcentrifuge tubes and centrifuged at $5000 \mathrm{rpm}$ at $4^{\circ} \mathrm{C}$ for 10 min. Cell pellets were then lysed in $300 \mu \mathrm{L}$ lysis buffer (Cytobuster protein extraction reagent, Novagen, Darmstadt, Germany) with $25 \mathrm{mM} \mathrm{NaF}, 1 \mathrm{mM} \mathrm{Na}_{3} \mathrm{VO}_{4}, 1 \times$ protease inhibitor cocktail. Protein concentrations were determined by standard Brandford assay. For Western blotting, equal amount of protein from each sample was loaded on SDS-PAGE and electrotransferred onto PVDF membranes (Millipore, Bedford, MA, USA). These membranes were then blocked with $5 \%(\mathrm{w} / \mathrm{v}$ ) bovine serum albumin in TBST [10 mM Tris, $150 \mathrm{mM} \mathrm{NaCl}$, and $0.1 \%(\mathrm{v} / \mathrm{v}$ ) Tween $20, \mathrm{pH}=7.5$ ] for $1 \mathrm{~h}$ at room temperature, and incubated with primary antibodies overnight at $4^{\circ} \mathrm{C}$. Secondary antibody incubation was at room temperature for $2 \mathrm{~h}$ (Santa Cruz Biotechnology). Chemiluminescence ECL (Amersham, Arlington Heights, IL, USA) was used to detect immunoreactive protein signals. Protein signals were then visualized on films and scanned and quantified using the ImageJ software (National Institutes of Health Image, USA). For re-probing, PVDF membranes were stripped with $0.2 \mathrm{M} \mathrm{NaOH}$ for 10 min before blocking with another primary antibody. The expression of interested molecules was determined relative to $\beta$-actin.

\section{Statistical analysis}

Each experiment was repeated at least three times. Quantified results were presented as mean \pm S.D. Significant differences were determined using factorial analysis of variance (ANOVA). P $<0.05$ was considered significant difference. 


\section{Cellular Physiology Cell Physiol Biochem 2012;30:123-136

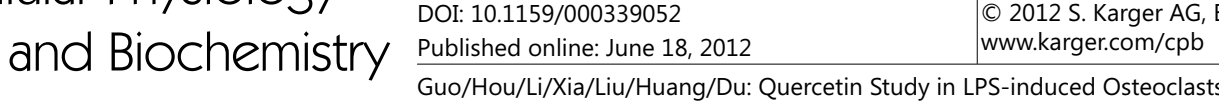

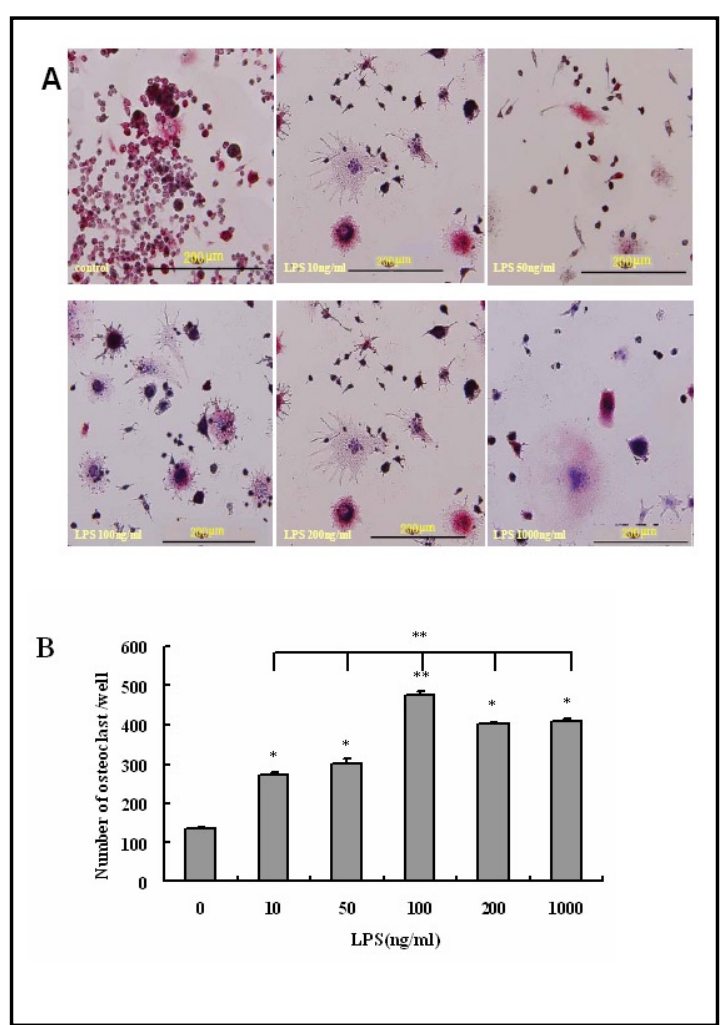

Fig. 1. Effect of LPS on osteoclast formation. A. TRAPpositive multinucleated cells at $4 \mathrm{~d}$ after LPS $(0,10$, $50,100,200$, or $1000 \mathrm{ng} / \mathrm{mL}$ ) treatment. B. The number of osteoclasts in LPS-treated $(0,10,50,100$, 200 , or $1000 \mathrm{ng} / \mathrm{mL})$ cultures. ${ }^{*} \mathrm{P}<0.05 ;{ }^{* *} \mathrm{P}<0.01$. Data represent the mean \pm S.D. from three independent experiments.

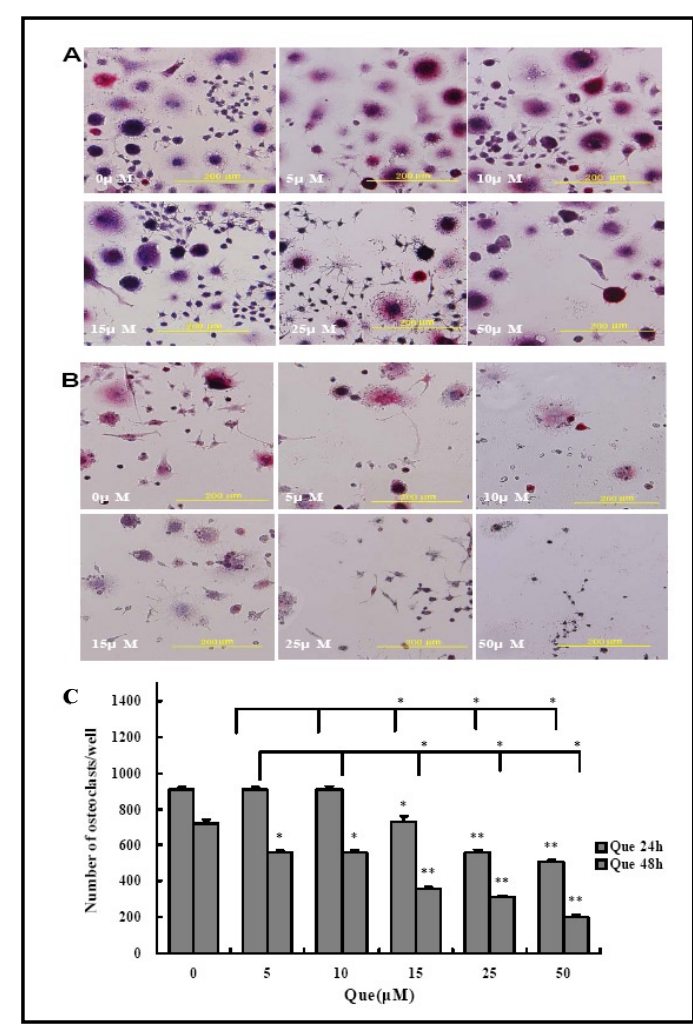

Fig. 2. The number of TRAP-positive multinucleated cells in osteoclasts treated with $5,10,15,25$ or $50 \mu \mathrm{M}$ quercetin in the presence of LPS $(100 \mathrm{ng} /$ $\mathrm{mL}$ ) for A. $24 \mathrm{~h}$ and B. $48 \mathrm{~h}$. C. Effect of quercetin treatments (at 15, 25 and $50 \mu \mathrm{M}$ ) on osteoclast survival at 24 and $48 \mathrm{~h} .{ }^{*} \mathrm{P}<0.05 ;{ }^{* *} \mathrm{P}<0.01$. Data represent the mean \pm S.D. from three independent experiments.

\section{Results}

\section{Quercetin inhibited LPS-induced mature osteoclast survival}

The population of osteoclasts in LPS-treated cultures was significantly higher than that in non-treated cultures. LPS at $100 \mathrm{ng} / \mathrm{mL}$ induced the most osteoclast formation among other concentrations of LPS treated cultures (Fig. 1). Further quercetin treatment at 15, 25 and $50 \mu \mathrm{M}$ significantly decreased the number of osteoclasts induced by LPS (Fig. 2A-C). Quercetin treatment at $50 \mu \mathrm{M}$ completely suppressed LPS-induced osteoclast formation at $48 \mathrm{~h}$ after the addition of quercetin (Fig. $2 \mathrm{C}$ ).

To ensure the inhibitory effect of quercetin on LPS-induced osteoclast survival, we evaluated cell viability in all treatment groups. Quercetin significantly decreased LPSinduced osteoclast viability in a dose-dependent manner at $24 \mathrm{~h}$ after quercetin treatment. Quercetin alone did not induce cytotoxicity in RAW264.7 cells at the concentrations used in the current study (Fig. 3).

Quercetin inhibited the mRNA expression of osteoclast-specific genes in mature osteoclasts

On differentiation day $4, \mathrm{LPS}$ at $100 \mathrm{ng} / \mathrm{mL}$ significantly increased mRNA expression of TRAP, MMP-9 and $C K$ than other concentrations of LPS treated groups as well as non-treated group. Messenger RNA expressions of TRAP, MMP-9 and $C K$ in LPS-induced osteoclasts were 


\section{Cellular Physiology $\quad$ Cell Physiol Biochem 2012;30:123-136 \\ \begin{tabular}{ll|l} 
and Biochemistry & DOI: 10.1159/000339052 & $\begin{array}{l}\text { Published online: June 18, } 2012 \\
\text { www.karger.com/cpb }\end{array}$ \\
\cline { 2 - 3 } Guo/Hou/Li/Xia/Liu/Huang/Du: Quercetin Study in LPS-induced Osteoclasts
\end{tabular}}

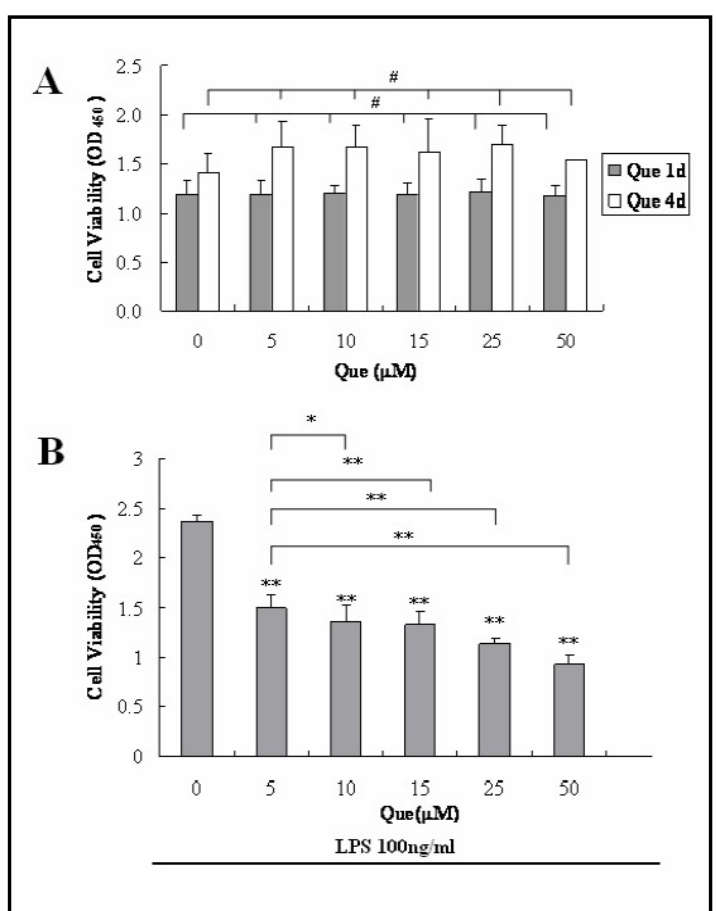

Fig. 3. Effect of quercetin on cell viability in (A) RAW264.7 cells at $24 \mathrm{~h}$ or $4 \mathrm{~d}$ and (B) LPS-induced mature osteoclasts at 24 h. ${ }^{*} \mathrm{P}<0.05 ;{ }^{* *} \mathrm{P}<0.01$. Data represent the mean \pm S.D. from three independent experiments.

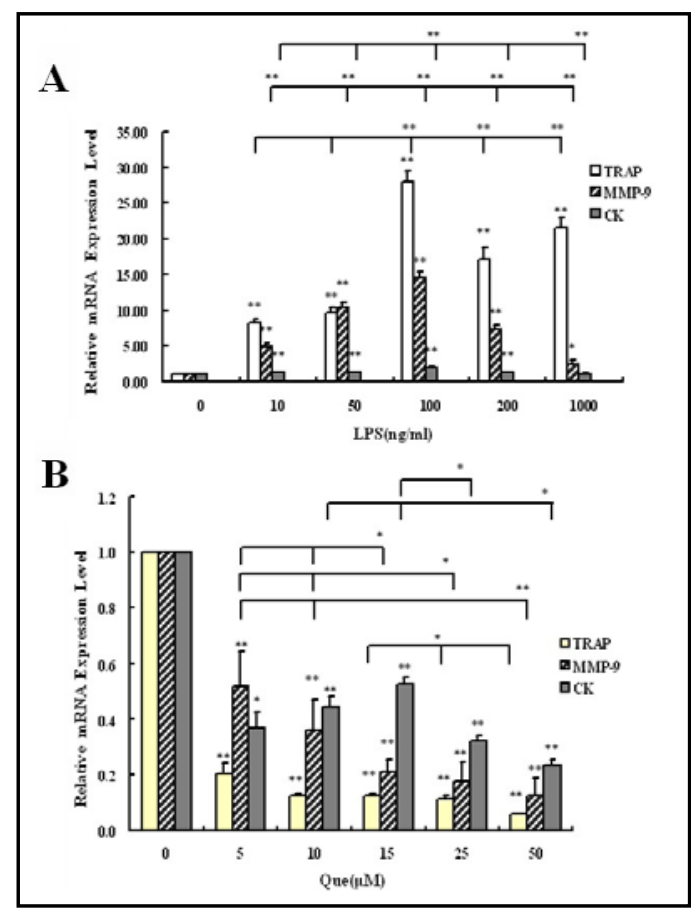

Fig. 4. Messenger RNA expression of TRAP, MMP9 and $C K$ in A. LPS treated $(0,10,50,100,200$, or $1000 \mathrm{ng} / \mathrm{mL})$ in RAW264.7 cells at day 4; and B. Quercetin treatment $(0,5,10,15,25$, or $50 \mu \mathrm{M})$ in LPS-induced osteoclasts at $24 \mathrm{~h} . * \mathrm{P}<0.05 ; * * \mathrm{P}$ $<0.01$. Data represent the mean \pm S.D. from three independent experiments.

significantly inhibited in a dose-dependent manner with the treatment of quercetin at 24 h (Fig. 4). Quercetin at 25 and $50 \mu \mathrm{M}$ exhibited complete inhibition on LPS induced mRNA expression of TRAP and MMP-9 in mature osteoclasts.

Quercetin inhibits the expression of RANK, TRAF6 and COX-2 protein in LPS-induced osteoclasts

LPS at 100ng/mL significantly increased protein expression of RANK, TRAF6 and COX-2; however, higher concentrations of LPS inhibited protein expression of these molecules (Fig. 5). Quercetin significantly inhibited RANK and COX-2 protein expression in a dose-dependent manner when compared to non-quercetin-treated LPS-induced osteoclasts at $24 \mathrm{~h}(\mathrm{P}<0.01)$ (Fig. 6). Quercetin at $50 \mu \mathrm{M}$ exhibited the highest inhibition on protein expression of TRAF6 when compared to other quercetin concentrations at $24 \mathrm{~h}$ (Fig. 6).

Quercetin selectively regulates activation of MAPK in LPS-induced osteoclasts

Since MAP kinases are important regulators of inflammatory mediators and osteoclast differentiation, we used densitometric scanning of Western blots to examine the effect of quercetin on activation of MAPKs in LPS-induced osteoclasts. Quercetin treatment at $50 \mu \mathrm{M}$ enhanced protein levels of phosphorylated forms of p38-MAPK, ERK1/2 and JNK in LPSinduced (100 ng/mL) osteoclasts at $2 \mathrm{~h}$ (Fig. 7).

MAPK inhibitors SB203580, PD98059 and SP600125 were added $2 \mathrm{~h}$ prior to quercetin treatment and then proteins were prepared $30 \mathrm{~min}$ after quercetin treatment in the presence of LPS (100 ng/mL). MAPK inhibitors, SB203580, PD98059 and SP600125, selectively attenuated quercetin-enhanced phosphorylation of p38-MAPK and JNK, but not the phosphorylation of ERK1/2 (Fig. 8). This suggests that quercetin inhibits LPS-induced 


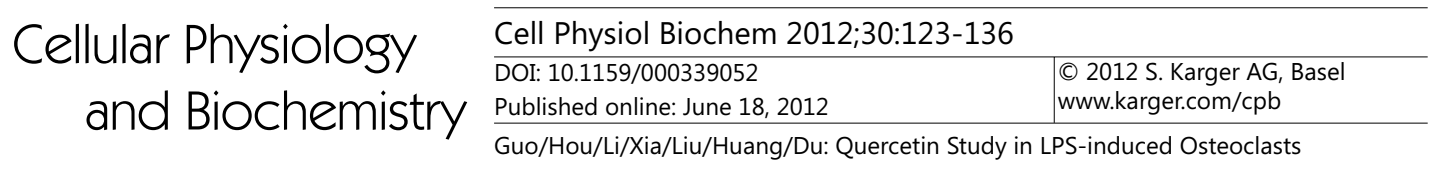

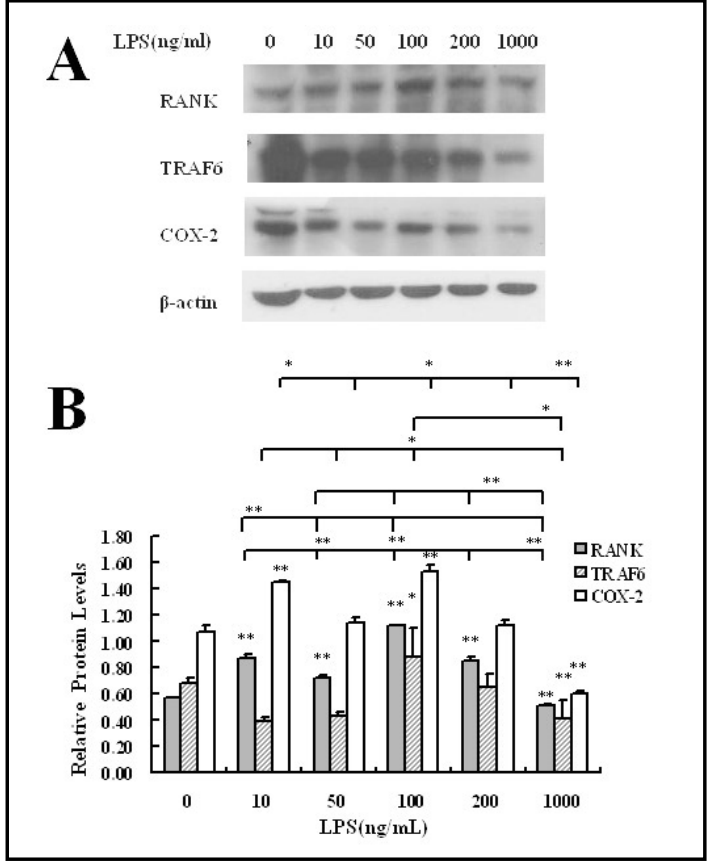

Fig. 5. A. Protein expression of RANK, TRAF6 and COX-2 after RAW264.7 cells treated with LPS $(0,10$, $50,100,200,1000 \mathrm{ng} / \mathrm{mL}$ ) for $4 \mathrm{~d}$. B. Effect of protein expression of RANK, TRAF6 and COX-2 under LPS at day $4 .{ }^{*} \mathrm{P}<0.05$; ${ }^{* *} \mathrm{P}<0.01$. Data represent the mean \pm S.D. from three independent experiments.

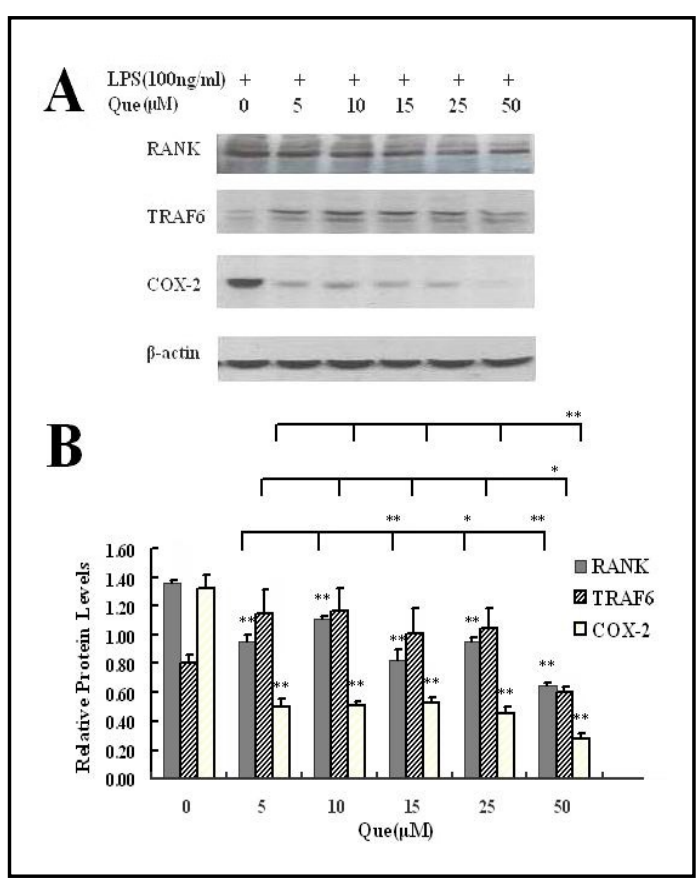

Fig. 6. A. Protein expression of RANK, TRAF6 and COX-2 at $24 \mathrm{~h}$ after quercetin treatment in LPSinduced osteoclasts. B. Effect of quercetin on protein expression of RANK and COX-2 at $24 \mathrm{~h}$ showing in a dose-dependent manner. ${ }^{*} \mathrm{P}<0.05$; ${ }^{* *} \mathrm{P}<0.01$. Data represent the mean \pm S.D. from three independent experiments.

osteoclast formation and bone resorptive activity through selective activations of p38-MAPK, and JNK, both of which are involved in the apoptotic signaling pathway. MAPK inhibitor PD98059 did not attenuate on quercetin-enhanced phosphorylation of ERK1/2. This is possibly because the ERK1/2 signaling pathway inhibits apoptotic processes.

\section{Effect of quercetin on cell apoptosis}

The effect of exposure to quercetin for $24 \mathrm{~h}$ on nuclear condensation was tested using Hoescht fluorescence. After incubation with LPS at $100 \mathrm{ng} / \mathrm{mL}$ for $4 \mathrm{~d}$, cells were treated with quercetin in the presence of LPS $(100 \mathrm{ng} / \mathrm{mL}$ ) for $24 \mathrm{~h}$. Hoechst 33258 staining was analyzed with a fluorescence microscope. Cells with nuclei containing condensed chromatin or cells with fragmented nuclei were defined as apoptotic cells. The number of fluorescence-positive osteoclasts was increased with quercetin treatment in a dose-dependent manner compared to non-quercetin-treated osteoclasts in the presence of LPS at $24 \mathrm{~h}$ (Fig. 9). Quercetin at 50 $\mu \mathrm{M}$ significantly increased Bax protein expression while inhibiting Bcl-2 protein expression compared to non-quercetin-treated cells in LPS induced osteoclasts (Fig. 10).

\section{Quercetin inhibits bone resorptive activity in LPS-induced osteoclasts}

RAW264.7 cells were plated on bovine bone slices and incubated with LPS $(100 \mathrm{ng} / \mathrm{mL})$ for $6 \mathrm{~d}$. Then administration of quercetin treated into mature osteoclasts in the presence of LPS (100ng/mL) every $3 \mathrm{~d}$. On day 15 , bone slices were stained with $1 \%$ toluidine blue- $1 \%$ borate for $5 \mathrm{~min}$. The number of pits in each bone slice was observed and counted using a microscope. The images were also obtained. Quercetin treatments at 15, 25 and $50 \mu \mathrm{M}$ concentrations decreased the number of pits in each bone slice significantly, indicating that osteoclast bone resorption was inhibited as a result of quercetin treatment in the presence of LPS (Fig. 11). 


\section{Cellular Physiology $\quad$ Cell Physiol Biochem 2012;30:123-136 \\ \begin{tabular}{ll|l} 
and Biochemistry & $\begin{array}{l}\text { DOI: 10.1159/000339052 } \\
\text { Published online: June 18, 2012 }\end{array}$ & $\begin{array}{l}\text { O 2012 S. Karger AG, Basel } \\
\text { www.karger.com/chb }\end{array}$ \\
\cline { 2 - 2 } & Guo/Hou/L//Xia/Liu/Huang/Du: Quercetin Study in LPS-induced Osteoclasts
\end{tabular}}

Fig. 7. A. and C. Effect of quercetin at $50 \mu \mathrm{M}$ on the protein expression of MAPKs in LPSinduced osteoclasts at $2 \mathrm{~h}$. Quercetin at $50 \mu \mathrm{M}$ enhanced activation of MAPKs on $30 \mathrm{~min}(\mathrm{P}<0.05)$. B D Quercetin at $0,5,10,15,25$ or $50 \mu \mathrm{M}$ was given to LPS-induced osteoclasts for 30 min and the protein expression ofMAPKs was examined. Quercetin at 50 $\mu \mathrm{M}$ enhanced the utmost activation of MAPKs $(\mathrm{P}<0.01)$. Data represent the mean \pm S.D. from three independent experiments.

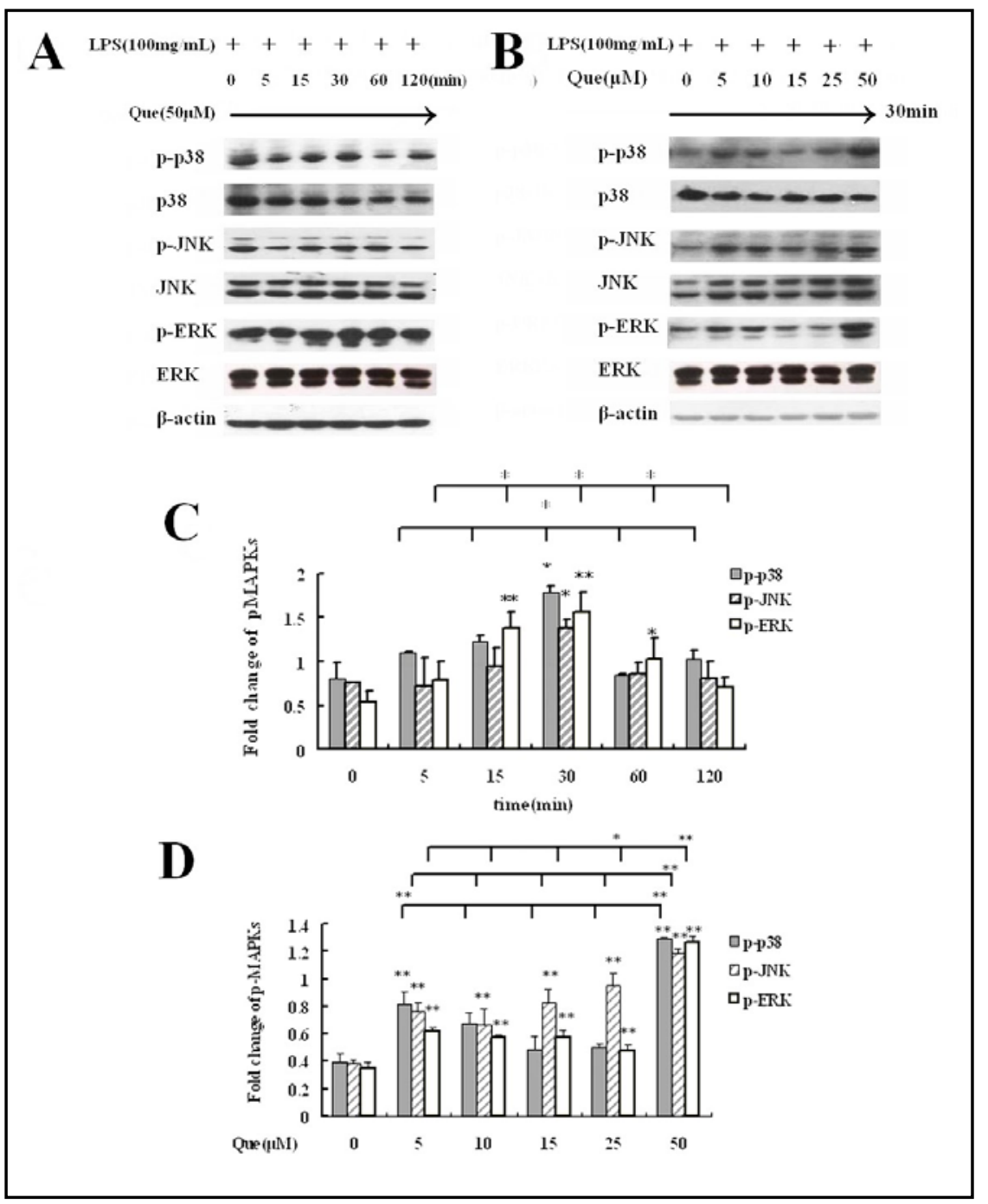

\section{Discussion}

Bacteria-induced inflammatory response is an important contributor to excessive bone resorption in chronic inflammatory diseases such as septic arthritis, osteomyelitis, and infected orthopedic implant failure [16]. LPS, a pro-inflammatory glycolipid and main component of the cell wall of Gram-negative bacteria, is well documented in Gram-negative bacteria-induced bone destruction. LPS stimulates osteoclastic bone resorption in vivo [17, 18 ] and promotes osteoclast differentiation in whole bone marrow cell culture [19] and in preosteoclasts $[6,7]$. In the current study, LPS increased the protein expression of RANK, TRAF6 and COX-2 and mRNA expression of TRAP, MMP-9 and CK in RAW264.7 cells (100 ng/ mL LPS). Compared with LPS-induced osteoclasts, the mRNA expression levels of osteoclastrelated genes in RAW264.7 cells were downregulated or unregulated by quercetin (data not shown). These results confirmed that LPS could stimulate osteoclast differentiation directly $[6,7]$.

Quercetin, as one of the most abundant flavonoids found in onions and other vegetables, has been highlighted as a bioactive substance and could be of potential clinical application in inflammatory diseases [13]. Quercetin has been reported to inhibit osteoclast formation and to prevent bone loss in ovariectomy (OVx) animal models [10-12, 20]. Moreover, in vivo evidence show that quercetin has a bone-protecting effect caused by estrogen deficiency, at least in part, by dual regulation of the enhancement of osteoblast function and the induction of osteoclast apoptosis [21]. However, the effect of quercetin on LPS-induced osteoclastogenesis has not yet been reported. 


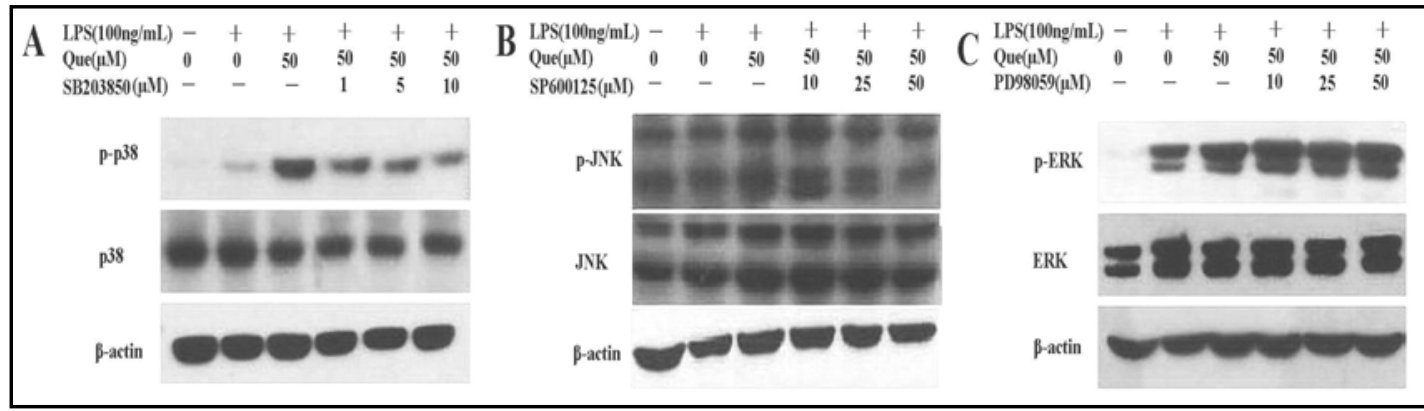

Fig. 8. Effect of quercetin on the protein expression and phosphorylation of MAPKsin LPS-induced osteoclasts in the presence of MAPK inhibitors A. SB203580, B. SP600125 and C. PD98059 at 30 min after quercetin treatment. ${ }^{*} \mathrm{P}<0.05 ;{ }^{* *} \mathrm{P}<0.01$. Data represent the mean \pm S.D. from three independent experiments.

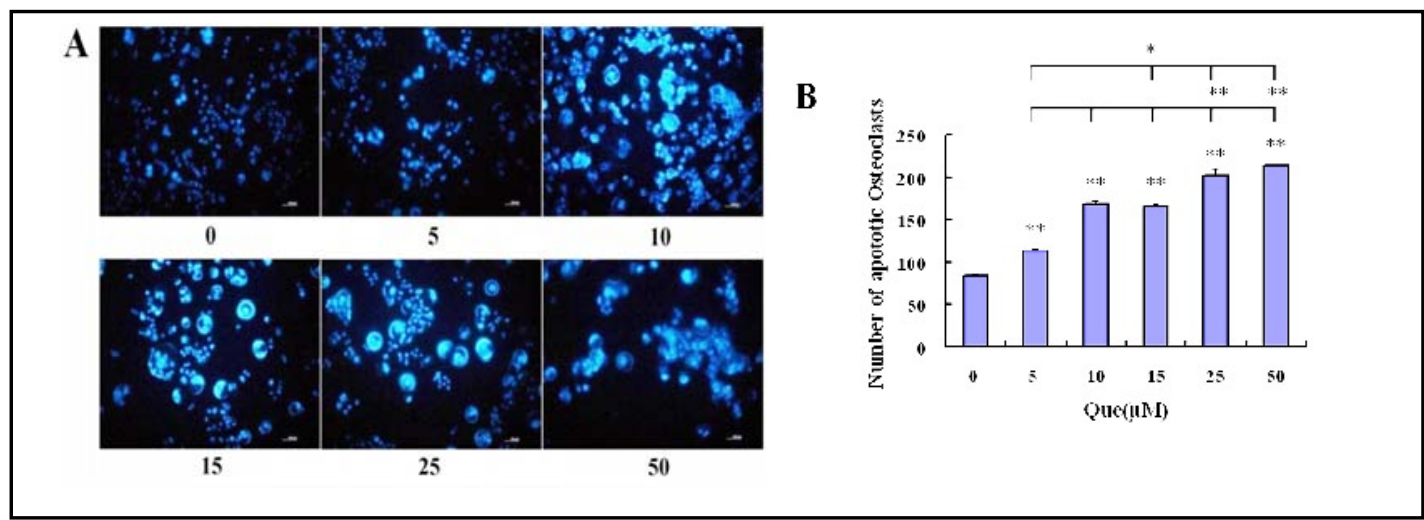

Fig. 9. A. Effect of quercetin on nuclei condensation (stained with Hoescht 33258) of mature osteoclasts at $24 \mathrm{~h}$. B. Number of fluorescence-positive osteoclasts induced by quercetin treatment at $24 \mathrm{~h}(0,5,10,15,25$, or $50 \mu \mathrm{M}) .{ }^{*} \mathrm{P}<0.05$; ${ }^{* *} \mathrm{P}<0.01$. Data represent the mean \pm S.D. from three independent experiments.

In the current study, we found that quercetin suppressed the expression of osteoclast related molecules, showing decreased mRNA expression of TRAP, MMP-9 and CK, as well as decreased protein expression of RANK, TRAF6 and COX-2 in LPS-induced osteoclasts. On differentiation day 5 and 6 , quercetin at 15,25 and $50 \mu \mathrm{m}$ significantly decreased the number of TRAP-positive multinucleated osteoclasts induced by LPS. Quercetin also significantly decreased LPS-induced osteoclast viability in a dose-dependent manner after $24 \mathrm{~h}$ without cytotoxicity in RAW264.7 cells. These data suggest that quercetin suppresses LPS-induced osteoclast survival and bone resorption. Quercetin at $50 \mu \mathrm{M}$ has exerted more potent inhibitory effect on LPS-induced osteoclast survival and bone resorption in vitro. The estimated average individual intake of quercetin in the United States is $25 \mathrm{mg}$ per day. In an American diet containing fried onions, quercetin glucosides is about $64 \mathrm{mg}$, equivalent to $64 \mathrm{mg}$ aglycone, which can reach a maximum serum concentration of $196 \mathrm{ng} / \mathrm{mL}$ (equals to $0.6 \mathrm{mM}$ ) $2.9 \mathrm{~h}$ after ingestion [22]. The same investigators experimented on nine healthy subjects by giving them the amount of quercetin glucosides equivalent to $64 \mathrm{mg}$ aglycone from onions. Plasma levels of quercetin reached the peak of $225 \mathrm{ng} / \mathrm{mL}$ (equals to $0.8 \mathrm{mM}$ ) after the onion meal [23]. Therefore, in the current report, treatment of quercetin at $50 \mu \mathrm{M}$ (equals to $15.1 \mathrm{ng} / \mathrm{mL}$ ) is a physiologically relevant dose.

The inhibitory effect of quercetin on LPS-induced osteoclast resorptive activity is confirmed by evaluating mRNA expression levels of osteoclast-related genes. TRAP has been suggested to be involved in bone resorptive activity in osteoclasts [24, 25]. The proteolytic enzymes such as MMP-9 and CK are highly expressed in osteoclasts. They are essential enzymes in degrading the bone matrix during bone resorption. MMP-9 can initiate the bone resorptive process by removing the collagenous layer from the bone surface before 


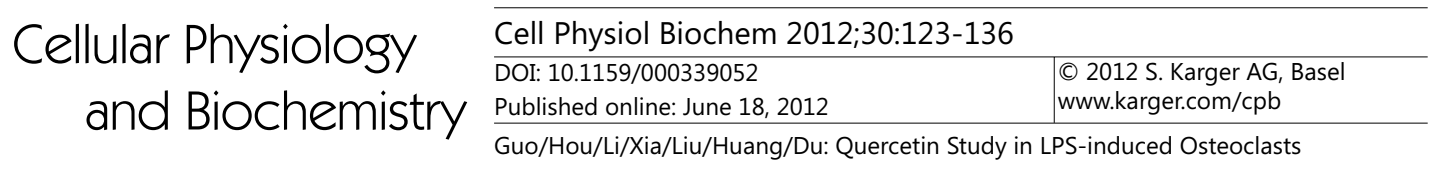

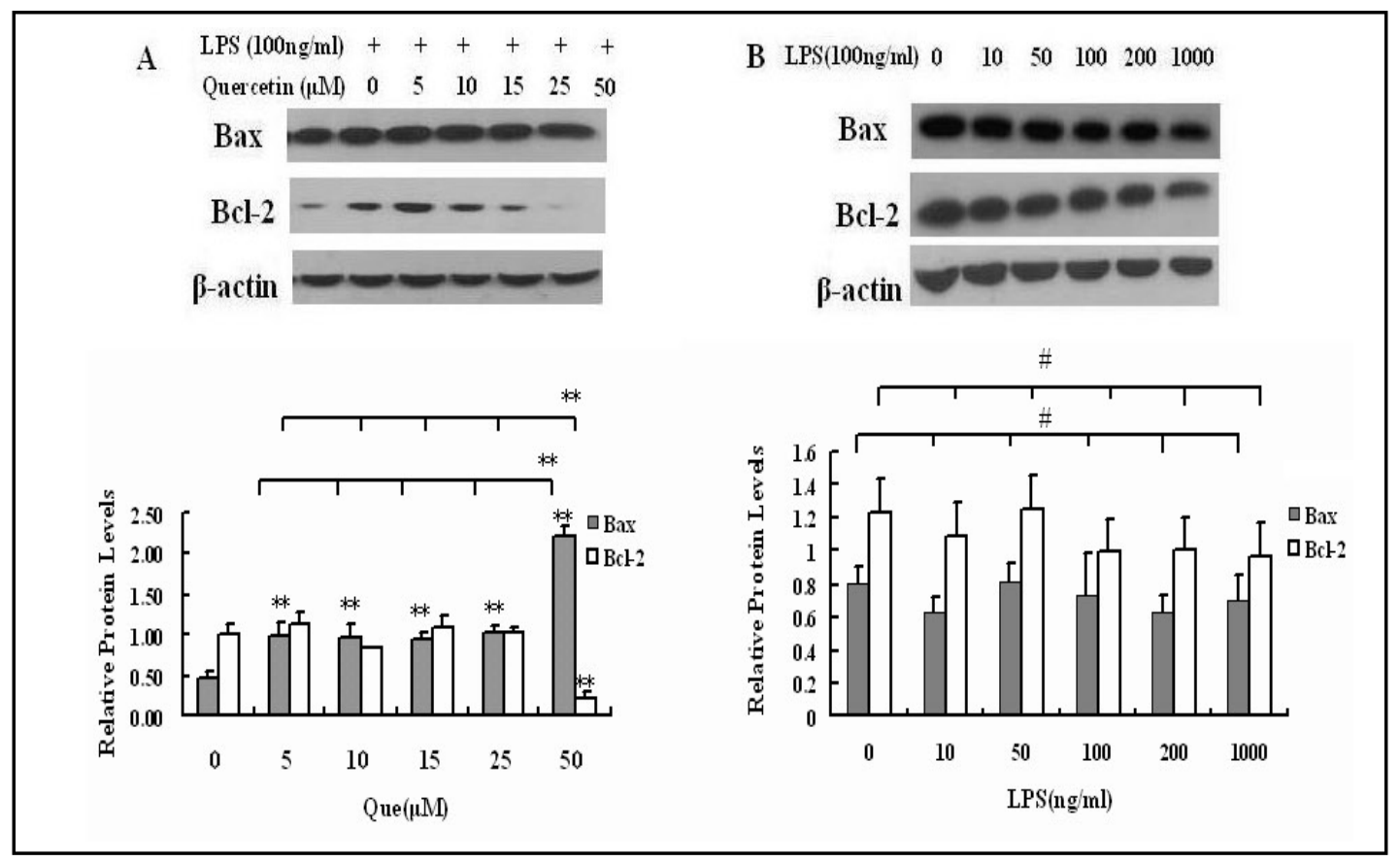

Fig. 10. Protein expression of Bax and Bcl-2 in A. LPS-induced mature osteoclasts treated with $0,5,10,15$, 25 , or $50 \mu \mathrm{M}$ quercetin at $24 \mathrm{~h}$; B. RAW264.7 cells treated with $0,10,50,100,200$ or $1000 \mathrm{ng} / \mathrm{mL}$ LPS for $4 \mathrm{~d}$. ${ }^{*} \mathrm{P}<0.05 ;{ }^{* *} \mathrm{P}<0.01$. Data represent the mean \pm S.D. from three independent experiments.

Fig. 11. A. The number of osteoclast bone resorption pits $15 \mathrm{~d}$ after quercetin treatments $(0,5,10,15,25$, or $50 \mu \mathrm{M})$. B. The effect of 15,25 and $50 \mu \mathrm{M}$ quercetin on osteoclast bone resorptive activity compared to nontreated culture. ${ }^{*} \mathrm{P}<0.05 ;{ }^{* *} \mathrm{P}<0.01$. Data represent the mean \pm S.D. from three independent experiments.

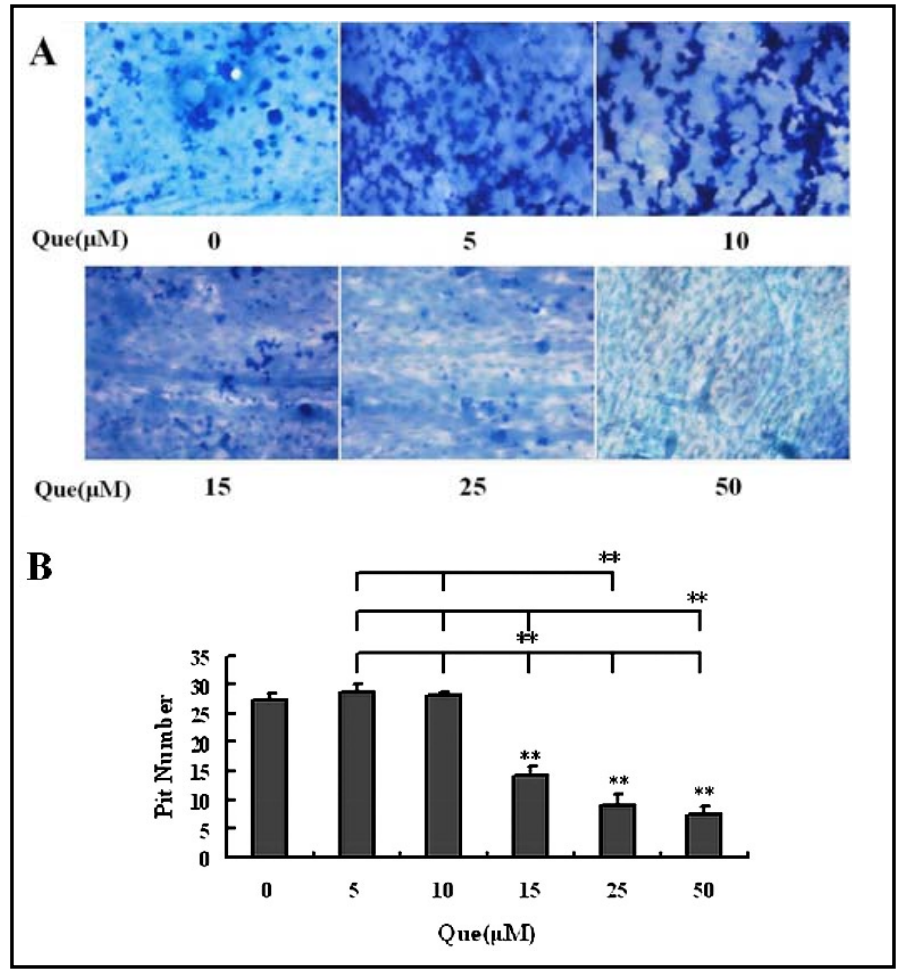

demineralization begins [26-28,]. CK plays an essential role in osteoclastic bone resorption [29-31]. In the current study, the mRNA expression levels of TRAP, MMP-9 and $C K$ as well as bone slices pit in LPS-induced osteoclast were significantly inhibited by quercetin treatment 
in a dose-dependent manner. Taken together, our data indicate that the inhibitory effect of quercetin on bone resorptive activity could be due to the inhibition of quercetin on osteoclastrelated genes.

Our data show that LPS can induce osteoclast differentiation from RAW264.7 cells on day 4; only from day 6 on the mature osteoclasts were functionally activated. Administration of quercetin to LPS-induced osteoclasts on differentiation day 4 for 24 or $48 \mathrm{~h}$ can evaluate the effect of quercetin on osteoclast survival or apoptosis in differentiated osteoclasts. Unreported data from our group also show that quercetin has a potent inhibitory effect on osteoclastogenesis induced by LPS when quercetin is administrated more than $2 \mathrm{~h}$ prior to treatment with LPS in RAW264.7 cells.

Induction of apoptosis in mature osteoclasts or suppressing the survival of mature osteoclasts has been suggested to be one of the processes to inhibit osteoclast-mediated bone loss [32]. We further evaluated the effect of quercetin on apoptosis in LPS-induced mature osteoclasts. Our data suggest that quercetin promoted apoptosis in LPS-induced mature osteoclasts in a dose-dependent manner. Moreover, quercetin promoted protein expression of Bax, while inhibiting Bcl-2. Based on these results, we conclude that the inhibitory effect of quercetin on bone resorptive activity also involves the induction of apoptosis in LPS-induced osteoclasts.

MAPKs are activated by a variety of stresses including LPS and then affect apoptosis either in positive or negative manners [33]. In many cell types, JNK and p38-MAPK contribute to the induction of apoptosis, whereas ERK1/2 inhibits apoptotic processes [34-36]. In the current study, treatment with quercetin enhanced phosphorylation of ERK1/2, p38-MAPK and JNK. However, re-treatment with MAPK inhibitors SB203580, PD98059 and SP600125 alone attenuated quercetin-enhanced phosphorylation of p38-MAPK and JNK, but not ERK1/2. These data suggests that quercetin can promote apoptosis in mature osteoclast through the p38-MAPK and JNK signaling pathways, which further inhibit LPS-induced osteoclast resorptive activity.

COX-2 plays a critical role in a number of osteoclastogenic signaling pathways [37, 38]. Inhibition of COX-2 blocks osteoclast formation in vitro $[39,40]$. In the current study, LPS upregulated the protein expression of COX-2 in RAW264.7 cells, whereas quercetin inhibited COX-2 expression in LPS-induced osteoclasts, indicating that the inhibitory effect of quercetin on COX-2 expression in LPS-induced osteoclasts also results in blocking LPS-induced osteoclastogenesis. Our results agreed with previous publications [39, 40].

RANK signal transduction has been reported to be essential for osteoclast differentiation, bone resorptive function, and survival [41,42]. Mice deficient in RANKL or RANKgenes exhibit severe osteopetrosis because they do not form osteoclasts [43-46]. Selective inhibition of RANK with RANK:Fc or RANK receptor inhibitor blocks osteoclast maturation and function in vivo or in vitro [47-50]. Selective inhibition of TRAF6 also blocks osteoclast maturation and function [41, 51]. Our results show that LPS enhanced protein expression of RANK and TRAF6 in RAW264.7 cells. However, quercetin can inhibit RANK protein expression in a dosedependent manner, while quercetin at $50 \mu \mathrm{M}$ decreases the protein expression of TRAF6 at $24 \mathrm{~h}$. This suggests that RANK/TRAF6 signaling plays a prominent role in osteoclastogenesis downstream of LPS, and quercetin inhibits mature osteoclast activities via RANK signal transduction.

In conclusion, our data suggest that quercetin can inhibit LPS-induced osteoclastogenesis and bone resorption. Our findings indicate that quercetin could be an effective drug to treat human abnormal bone loss induced by LPS in chronic inflammatory diseases.

\section{Acknowledgements}

This study was supported by the Administration of Traditional Chinese Medicine of Guangdong Province, China (No.2010186). Disclosure: The authors declare no conflicts of financial interest. 


\section{Cellular Physiology Cell Physiol Biochem 2012;30:123-136 \begin{tabular}{ll|l} 
and BiOchemistry & $\begin{array}{l}\text { DOI: 10.1159/000339052 } \\
\text { Published online: June 18, } 2012\end{array}$ & $\begin{array}{l}\text { C) 2012 S. Karger AG, Basel } \\
\text { www.karger.com/cpb }\end{array}$ \\
\cline { 2 - 3 }
\end{tabular} Guo/Hou/Li/Xia/Liu/Huang/Du: Quercetin Study in LPS-induced Osteoclasts}

\section{References}

1 Roodman D: Advances in bone biology: the osteoclast. Endocr Rev 1996;17:308-332.

2 Suda T, Takahashi N, Udagawa N, Jimi E, Gillespie M T, Martin T J: Modulation of osteoclast differentiation and function by the new members of the tumor necrosis factor receptor and ligand families. Endocr Rev 1999;20:345-357.

3 Boyle WJ, Simonet WS, Lacey DL: Osteoclast differentiation and activation. Nature 2003;423:337-342.

4 Shuto T, Jimi E, Kukita T, Hirata M, Koga T: Granulocytemacrophage colony stimulating factor suppresses lipopolysaccharide-induced osteoclast-like cell formation in mouse bone marrow cultures. Endocrinology 1994;134:831-837.

5 Abu-Amer Y, Ross FP, Edwards J, Teitelbaum SL: Lipopolysaccharide-stimulated osteoclastogenesis is mediated by tumor necrosis factor via its P55 receptor. J Clin Invest 1997;100:1557-1565.

6 Islam S, Hassan F, Tumurkhuu G, Dagvadorj J, Koide N, Naiki Y, Mori I, Yoshida T, Yokochi T: Bacterial lipopolysaccharide induces osteoclast formation in RAW 264.7 macrophage cells. Biochem Biophys Res Commun 2007;360:346-351.

7 Mörmann M, Thederan M, Nackchbandi I, Giese T, Wagner C, Hänsch GM: Lipopolysaccharides (LPS) induce the differentiation of human monocytes to osteoclasts in a tumour necrosis factor (TNF) alpha-dependent manner: a link between infection and pathological bone resorption. Mol Immunol 2008;45:3330-3337.

8 Itoh K, Udagawa N, Kobayashi K, Suda K, Li X, Takami M, Okahashi N, Nishihara T, Takahashi N: Lipopolysaccharide Promotes the Survival of Osteoclasts Via Toll-Like Receptor 4, but Cytokine Production of Osteoclasts in Response to Lipopolysaccharide Is Different from That of Macrophages. J Immunol 2003;170:3688-3695

9 Takami M, Kim N, Rho J, Choi Y: Stimulation by toll-like receptors inhibits osteoclast differentiation. J Immunol 2002;169:1516-1523.

10 Wattel A, Kamel S, Mentaverri R, Lorget F, Prouillet C, Petit JP, Fardelonne P, Brazier M: Potent inhibitory effect of naturally occurring flavonoids quercetin and kaempferol on in vitro osteoclastic bone resorption. Biochem Pharmacol 2003;65:35-42.

11 Woo JT, Nakagawa H, Notoya M, Yonezawa T, Udagawa N, Lee IS, Ohnishi M, Hagiwara H, Nagai K: Quercetin suppresses bone resorption by inhibiting the differentiation and activation of osteoclasts. Biol Pharm Bull 2004;27:504-509.

12 Siddiqui JA, Swarnkar G, Sharan K, Chakravarti B, Gautam AK, Rawat P, Kumar M, Gupta V, Manickavasagam L, Dwivedi AK, Maurya R, Chattopadhyay N: A naturally occurring rare analog of quercetin promotes peak bone mass achievement and exerts anabolic effect on osteoporotic bone. Osteoporos Int 2011;22:30133027.

13 Gutiérrez-Venegas G, Jiménez-Estrada M, Maldonado S: The effect of flavonoids on transduction mechanisms in lipopolysaccharide-treated human gingival fibroblasts. Int Immunopharmacol. 2007;7:1199-1210.

14 Kim MH, Ryu SY, Choi JS, Min YK, Kim SH. Saurolactam inhibits osteoclast differentiation and stimulates apoptosis of mature osteoclasts. J Cell Physiol 2009;221:618-628.

15 Livak KJ, Schmittgen TD. Analysis of relative gene expression data using real-time quantitative PCR and the 2(-Delta Delta C (T)) Method. Methods 2001;25:402-408.

16 Nair SP, Meghji S, Wilson M, Reddi K, White P, Henderson B: Bacterially induced bone destruction: Mechanisms and misconceptions. Infect Immun 1996;64:2371-2380.

17 Orcel P, Feuga M, Bielakoff J, De Vernejoul MC: Local bone injections of LPS and M-CSF increase bone resorption by different pathways in vivo in rats. Am J Physiol 1993:264:E391-E397.

18 Chiang CY, Kyritsis G, Graves DT, Amar S: Interleukin-1 and tumor necrosis factor activities partially account for calvarial bone resorption induced by local injection of lipopolysaccharide. Infect Immun 1999;67:4231-4236.

19 Ito HO, Shuto T, Takada H, Koga T, Aida Y, Hirata M, Koga T: Lipopolysaccharides from Porphyromonas gingivalis, Prevotella intermedia and Actinobacillus actinomycetemcomitans promote osteoclastic differentiation in vitro. Arch oral biol 1996:41:439-444.

20 Horcajada-Molteni MN, Crespy V, Coxam V, Davicco MJ, Remesy C, Barlet JP: Rutin inhibits ovariectomyinduced osteopenia in rats. J Bone Miner Res 2000;15:2251-2258. 


\section{Cellular Physiology Cell Physiol Biochem 2012;30:123-136 \begin{tabular}{ll|l} 
and BiOChemistry & $\begin{array}{l}\text { DOI: 10.1159/000339052 } \\
\text { Published online: June 18, } 2012\end{array}$ & $\begin{array}{l}\text { C 2012 S. Karger AG, Basel } \\
\text { www.karger.com/cpb }\end{array}$ \\
\cline { 2 - 3 } Guo/Hou/Li/Xia/Liu/Huang/Du: Quercetin Study in LPS-induced Osteoclasts
\end{tabular}}

21 Hee Do S, DVM, Lee JW, Jeong WI, Chung JY, Park SJ, Hong IH, Jeon SK, Lee IS, Jeong KS: Bone-protecting effect of Rubus coreanus by dual regulation of osteoblasts and osteoclasts. Menopause 2008;15:676-668.

22 Hollman PCH, Gaag MVD, Mengelers MJB, et al. Absorption and disposition kinetics of the dietary antioxidant quercetin in man. Free Rad Biol Med 1996;21:703-707.

23 Hollman PCH, van Trijp JMP, Mengelers MJB, et al. Bioavailability of the dietary antioxidant flavonol quercetin in man. Cancer Lett 1997;114:139-140.

24 Halleen JM, Raisanen S, Salo JJ, Reddy SV, Roodman GD, Hentunen TA, Lehenkari PP, Kaija H, Vihko P, Vaananen HK: Intracellular fragmentation of bone resorption products by reactive oxygen species generated by osteoclastic tartrate-resistant acid phosphatase. J Biol Chem 1999;274:22907-22910.

25 Angel NZ, Walsh N, Forwood MR, Ostrowski MC, Cassady AI, Hume DA: Transgenic mice overexpressing tartrate-resistant acid phosphatase exhibit an increased rate of bone turnover. J Bone Miner Res 2000;15:103-110.

26 Reponen P, Sahlberg C, Munaut C, Thesleff I, Tryggvason K: High expression of 92-kD type IV collagenase (gelatinase B) in the osteoclast lineage during mouse development. J Cell Biol 1994;124:1091-1102.

27 Yu X, Huang Y, Collin-Osdoby P, Osdoby P: Stromal cell-derived factor-1 (SDF-1) recruits osteoclast precursors by inducing chemotaxis, matrix metalloproteinase-9 (MMP-9) activity, and collagen transmigration. J Bone Miner Res 2003;18:1404-1418.

28 Samanna V, Ma T, Mak TW, Rogers M, Chellaiah MA: Actin polymerization modulates CD44 surface expression, MMP-9 activation, and osteoclast function. J Cell Physiol 2007;213:710-720.

29 Wilson SR, Peters C, Saftig P, Brömme D: Cathepsin K activity-dependent regulation of osteoclast actin ring formation and bone resorption. J Biol Chem 2009;284:2584-2592.

30 Ishikawa T, Kamiyama M, Tani-Ishii N, Suzuki H, Ichikawa Y, Hamaguchi Y, Momiyama N, Shimada H: Inhibition of osteoclast differentiation and bone resorption by cathepsin $\mathrm{K}$ antisense oligonucleotides. Mol Carcinog 2001;32:84-91.

31 Kozloff KM, Quinti L, Patntirapong S, Hauschka PV, Tung CH, Weissleder R, Mahmood U: Non-invasive optical detection of cathepsin K-mediated fluorescence reveals osteoclast activity in vitro and in vivo. Bone 2009;44:190-198.

32 Stern PH: Antiresorptive agents and osteoclast apoptosis. J Cell Biochem 2007; 101:1087-1096.

33 Pearson G, Robinson F, Beers Gibson T, Xu BE, Karandikar M, Berman K, Cobb MH: Mitogen-activated protein (MAP) kinase pathways: regulation and physiological functions. Endocr Rev 2001; 22: 153-183.

34 Xia Z, Dickens M, Raingeaud J, Davis RJ, Greenberg ME: Opposing effects of ERK and JNK-p38 MAP kinases on apoptosis. Science 1995;270:1326-1331.

35 Fister S, Günthert AR, Aicher B, Paulini KW, Emons G, Gründker C: GnRH-II antagonists induce apoptosis in human endometrial, ovarian, and breast cancer cells via activation of stress-induced MAPKs p38 and JNK and proapoptotic protein Bax. Cancer Res 2009;69:6473-6481.

36 Park GB, Kim YS, Lee HK, Song H, Cho DH, Lee WJ, Hur DY: Endoplasmic reticulum stress-mediated apoptosis of EBV-transformed B cells by cross-linking of CD70 is dependent upon generation of reactive oxygen species and activation of p38 MAPK and JNK pathway. J Immunol 2010;185:7274-7284.

37 Li L, Pettit AR, Gregory LS, Forwood MR. Regulation of bone biology by prostaglandin endoperoxide H synthases (PGHS): a rose by any other name.....Cytokine Growth Factor Rev 2006;17:203-216.

38 Ono K, Akatsu T, Murakami T, Kitamura R, Yamamoto M, Shinomiya N, Rokutanda M, Sasaki T, Amizuka $\mathrm{N}$, Ozawa H, Nagata N, Kugai N: Involvement of cyclooxygenase-2 in osteoclast formation and bone destruction in bone metastasis of mammary carcinoma cell lines. J Bone Miner Res 2002;17:774-781.

39 Ono K, Akatsu T, Kugai N, Pilbeam CC, Raisz LG: The effect of deletion of cyclooxygenase-2, prostaglandin receptor EP2, or EP4 in bone marrow cells on osteoclasts induced by mouse mammary cancer cell lines. Bone 2003;33:798-804.

40 Kellinsalmi M, Parikka V, Risteli J, Hentunen T, Leskelä HV, Lehtonen S, Selander K, Väänänen K, Lehenkari $\mathrm{P}$ : Inhibition of cyclooxygenase-2 down-regulates osteoclast and osteoblast differentiation and favours adipocyte formation in vitro. Eur J Pharmacol 2007;572:102-110.

41 Armstrong AP, Tometsko ME, Glaccum M, Sutherland CL, Cosman D, Dougall WC: A RANK/TRAF6dependent signal transduction pathway is essential for osteoclast cytoskeletal organization and resorptive function. J Biol Chem 2002;277:44347-44356. 


\section{Cellular Physiology \\ Cell Physiol Biochem 2012;30:123-136 and Biochemistry

\begin{tabular}{l|l}
\hline DOI: $10.1159 / 000339052$ & $\begin{array}{l}\text { C } 2012 \text { S. Karger AG, Basel } \\
\text { www.karger.com/cpb }\end{array}$ \\
Published online: June 18, 2012 & Pw.
\end{tabular} \\ Guo/Hou/Li/Xia/Liu/Huang/Du: Quercetin Study in LPS-induced Osteoclasts}

42 Crockett JC, Mellis DJ, Scott DI, Helfrich MH: New knowledge on critical osteoclast formation and activation pathways from study of rare genetic diseases of osteoclasts: focus on the RANK/RANKL axis. Osteoporos Int 2011;22:1-20.

43 Kong YY, Yoshida H, Sarosi I, Tan HL, Timms E, Capparelli C, Morony S, Oliveira-dos-Santos AJ, Van G, Itie A, Khoo W, Wakeham A, Dunstan CR, Lacey DL, Mak TW, Boyle WJ, Penninger JM: OPGL is a key regulator of osteoclastogenesis, lymphocyte development and lymph-node organogenesis. Nature 1999;397:315-323.

44 Kim N, Odgren PR, Kim DK, Marks SC Jr, Choi Y: Diverse roles of the tumor necrosis factor family member TRANCE in skeletal physiology revealed by TRANCE deficiency and partial rescue by a lymphocyteexpressed TRANCE transgene. Proc Natl Acad Sci U S A 2000;97:10905-10910.

45 Li J, Sarosi I, Yan XQ Morony S, Capparelli C, Tan HL, McCabe S, Elliott R, Scully S, Van G, Kaufman S, Juan SC, Sun Y, Tarpley J, Martin L, Christensen K, McCabe J, Kostenuik P, Hsu H, Fletcher F, Dunstan CR, Lacey DL, Boyle WJ: RANK is the intrinsic hematopoietic cell surface receptor that controls osteoclastogenesis and regulation of bone mass and calcium metabolism. Proc Natl Acad Sci U S A 2000;97:1566-1571.

46 Dougall WC, Glaccum M, Charrier K, Rohrbach K, Brasel K, De Smedt T, Daro E, Smith J, Tometsko ME, Maliszewski CR, Armstrong A, Shen V, Bain S, Cosman D, Anderson D, Morrissey PJ, Peschon JJ, Schuh J: RANK is essential for osteoclast and lymph node development. Genes Dev 1999;13:2412-2424.

47 Li P, Schwarz EM, O’Keefe RJ, Ma L, Boyce BF, Xing L: RANK signaling is not required for TNFalpha-mediated increase in CD11 (hi) osteoclast precursors but is essential for mature osteoclast formation in TNF alphamediated inflammatory arthritis. J Bone Miner Res 2004;19:207-213.

48 Feeley BT, Liu NQ Conduah AH, Krenek L, Roth K, Dougall WC, Huard J, Dubinett S, Lieberman JR: Mixed metastatic lung cancer lesions in bone are inhibited by noggin overexpression and RANK:Fc administration. J Bone Miner Res. 2006;21:1571-1580.

49 Childs LM, Paschalis EP, Xing L, Dougall WC, Anderson D, Boskey AL, Puzas JE, Rosier RN, O’Keefe RJ, Boyce $\mathrm{BF}$, Schwarz EM: In vivo RANK signaling blockade using the receptor activator of NF- $\kappa B$ :Fc effectively prevents and ameliorates wear debris-induced osteolysis via osteoclast depletion without inhibiting osteogenesis. J Bone Miner Res 2002;17:192-199.

50 Kim H, Choi HK, Shin JH, Kim KH, Huh JY, Lee SA, Ko CY, Kim HS, Shin HI, Lee HJ, Jeong D, Kim N, Choi Y, Lee SY: Selective inhibition of RANK blocks osteoclast maturation and function and prevents bone loss in mice. J Clin Invest 2009a;119:813-825.

51 Poblenz AT, Jacoby JJ, Singh S, Darnay BG: Inhibition of RANKL-mediated osteoclast differentiation by selective TRAF6 decoy peptides. Biochem Biophys Res Commun 2007;359:510-515. 